\title{
Influence of parental and socioeconomic factors on stunting in children under 5 years in Egypt
}

\author{
L.K. Zottarelli, ${ }^{1}$ T.S. Sunil ${ }^{2}$ and S. Rajaram ${ }^{3}$
}

$$
\begin{aligned}
& \text { تأثير الحخصائص الو الدية والاجتماعية - الاقتصادية على التثزّم لدى الأطفال دون سن الحامسة في } \\
& \text { ليزاك زوتاريللي، ثانكام سونيل، سوبرامنيان راجارام }
\end{aligned}
$$

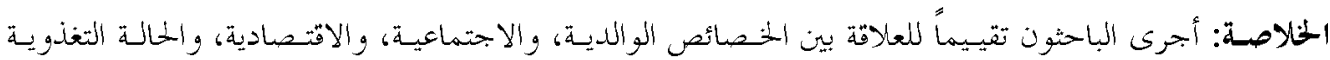

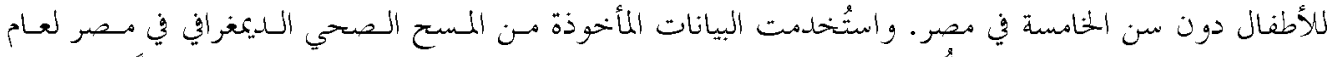

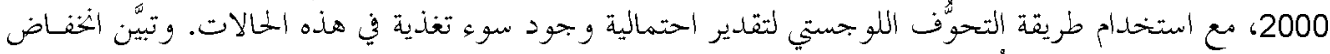

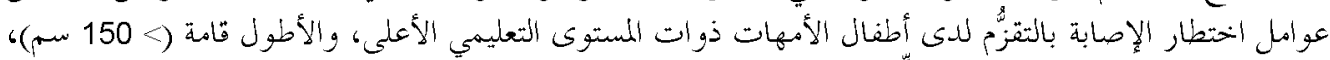

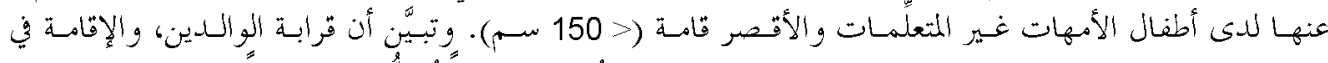

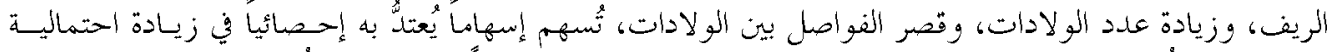

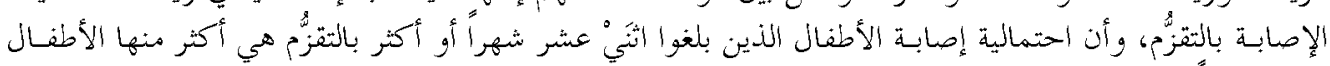

$$
\begin{aligned}
& \text { 12> شهراً. }
\end{aligned}
$$

ABSTRACT We assessed the relationship between parental and socioeconomic characteristics and nutritional status of children under 5 years in Egypt. Data from the 2000 Egypt Demographic and Health Survey were used. A logistic regression technique was used to estimate the odds of being malnourished. Children whose mothers had a higher level of education and were $>150 \mathrm{~cm}$ had a lower risk of stunting than those of mothers with no education and shorter height $(<150 \mathrm{~cm})$. Parental consanguinity, rural residence, high birth order and short birth interval significantly increased the odds of stunting. Children aged $\geq 12$ months had greater odds of stunting than those $<12$ months.

Influence des caractéristiques parentales et socio-économiques sur le retard de croissance chez l'enfant de moins de 5 ans en Égypte

RÉSUMÉ Nous avons évalué le rapport entre les caractéristiques parentales et socio-économiques et l'état nutritionnel des enfants de moins de 5 ans en Égypte. Pour ce faire, nous avons utilisé les données de l'enquête 2000-EDHS (2000 Egypt Demographic and Health Survey - Enquête sur la démographie et la santé en Égypte en 2000). La probabilité d'une malnutrition a été estimée selon la méthode de la régression logistique. Le risque de retard de croissance s'est avéré plus faible chez les enfants nés de mères possédant un niveau d'instruction relativement élevé et mesurant plus de $150 \mathrm{~cm}$ que chez ceux nés de femmes n'ayant reçu aucune instruction et de petite taille $(<150 \mathrm{~cm})$. La consanguinité parentale, la ruralité, les premiers rangs dans la fratrie et la brièveté de l'intervalle génésique sont autant de facteurs augmentant significativement la probabilité de déficit staturo-pondéral. Cette probabilité s'est avérée plus élevée chez l'enfant de 12 mois et plus que chez celui âgé de moins de 12 mois.

${ }^{1}$ Texas Woman's University, Texas, United States of America.

${ }^{2}$ University of Texas at San Antonio, San Antonio, Texas, United States of America (Correspondence to T.S Sunil: thankam.sunil@utsa.edu).

${ }^{3}$ Population Research Center, Dharwad, India.

المجلة الصحية لشرق المتو سط، منظمة الصحة العالمية، المجلد الثالث عشر، العدد ؟، V ... 


\section{Introduction}

Over the past 35 years, Egyptian demographic and survival indicators have shown marked improvement. For example, from 1970 to 2005 life expectancy increased from 52.1 years to 68.8 years, infant mortality dropped from 157 to 35 deaths per 1000 live births, and under-5 mortality dropped from 235 to 41 deaths per 1000 live births [1]. Despite these improvements in health conditions there are still important impediments to survival and development, especially for children. One of the most serious health concerns is under-nutrition. Figure 1 presents the trends in under-nutrition levels in children in Egypt from 1992-2000 [1]. While there are decreases in levels of child under-nutrition, approximately 1 in 10 children $(11 \%)$ under the age of 5 years was under-weight and approximately 1 in 5 children $(21 \%)$ was under-height for age [2].

The nutritional level in children is a vital component to their survival and development in their early years. Low levels of nutrition among children cause serious long- and short-term consequences in their physical and mental growth. Studies report high levels of mortality among malnourished children [3]. Further, malnourished children are more likely to have functional impairment in adult life [4] leading to a reduction in productive life and thus affecting the overall economic productivity of the society [5]. For example, it is widely accepted that adults who survive malnutrition as children are more likely to suffer from higher levels of chronic illness and disability $[6,7]$.

Studies on the nutritional status of children often accept the notion that it is determined by a multiplicity of factors [7-9]. In this regard, several theoretical explanations of malnutrition among children are found in the literature [10]. These include family planning approaches $[11,12]$, socioeconomic approaches $[9,13]$ and the framework recommended by UNICEF [14]. The former 2 approaches emphasize a set of factors to the exclusion of factors important to the

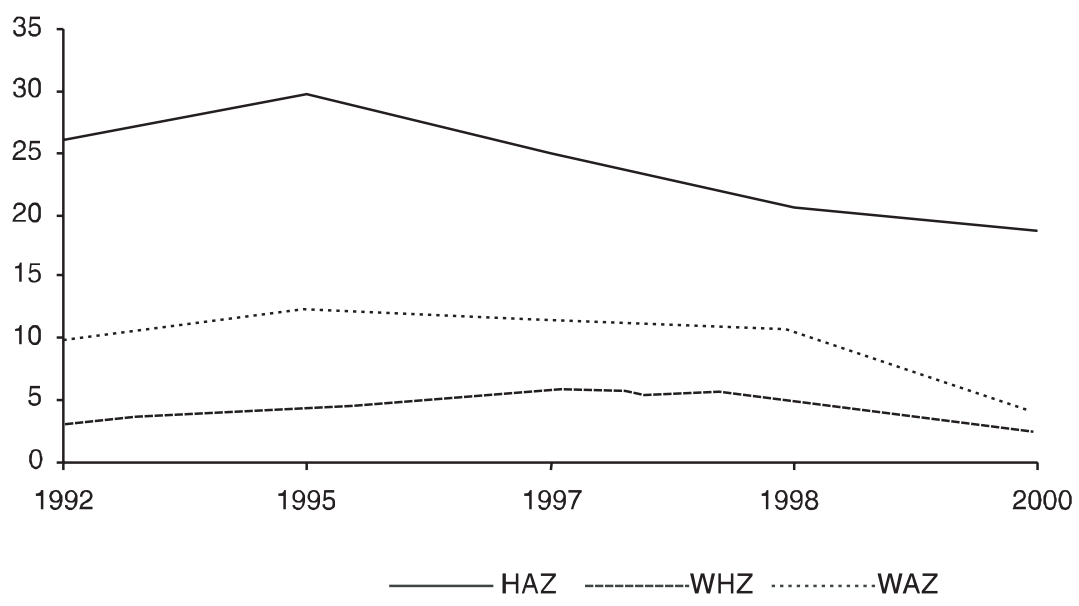

Figure 1 Trends in nutritional levels in children, Egypt 1992-2000 (HAZ = height-for-age, WHZ = weight-for-height, WAZ = weight-for-age). Source: [1]

المجلة الصحية لشرق المتو سط، منظمة الصحة العالمية، المجلد الثالث عشر، العدد Y، V... 
other approach. However, the UNICEF framework provides a holistic and pragmatic approach, in addition to addressing the limitations in other approaches, to the study of nutrition of children in developing countries. This framework follows "The triple A approach" (assessment, analysis and action) strategy to improve nutritional levels in children [14]. Furthermore, the framework classifies the causes of malnutrition and death into 3 categories that account for the complexity of the nutritional status of children: basic causes at the societal level, underlying causes at the household/ family level, and immediate causes. While this framework has strengths, one of the major limitations is that many existing secondary data sources do not allow researchers to follow this framework in its entirety in understanding child nutrition. The Egypt Demographic Health Survey [1], while not allowing as comprehensive an approach as would be ideal, provides variables that can be used within the basic and underlying causes identified in the framework. Furthermore, the present study incorporates family planning, demographic and socioeconomic approaches within the UNICEF framework.

Studies on child malnutrition in Egypt are often area-specific $[15,16]$ and many studies are limited to clinical approaches $[17,18]$. These studies have not explored fully the influence of parental and socioeconomic characteristics within the UNICEF framework. While the earlier studies are important contributions to the literature on Egyptian malnutrition, further research is needed to understand the influence of the underlying and basic causes determining the nutritional status of children in Egypt. The purpose of this paper therefore was to explore basic and underlying factors determining the nutritional status of children in Egypt.

\section{Methods}

\section{Data source}

The data for the present study come from the 2000 Egypt Demographic and Health Survey (EDHS) [1]. The 2000 EDHS was the sixth in the series of Demographic and Health Surveys conducted in Egypt. Similar to the other surveys, data were collected on fertility, family planning, infant and child mortality, and maternal and child health and nutrition. A nationally representative sample of 15573 ever-married women aged 15-49 years were interviewed. This survey included 2 questionnaires: a household questionnaire and an individual questionnaire. The household questionnaire consisted of questions related to household social and economic characteristics. The individual questionnaire included respondent's background (ever married women between 15-49 years), reproduction, contraceptive knowledge and use, fertility preferences and attitudes about family planning, pregnancy and breastfeeding, immunization and health, schooling of children and child labour, female genital mutilation, marriage and husband's background and woman's work and residence [1].

The primary objective of the EDHS 2000 survey was to provide reliable estimates for fertility and child mortality for the country and for 6 major administrative regions. The methodology of the survey is described in full in the EDHS report [1]. Briefly, a 3-stage design was used to collect a representative sample by which 17521 households were selected for the survey. From these households, the fully trained field staff interviewed 16957 of the sample households, for a response rate of $99 \%$. All ever-married women between 15 and 49 years of age were eligible to participate in the survey. As a quality control measure 
$10 \%$ of the households were selected for re-interview [1].

\section{Data analysis}

To assess the nutritional status of individual children, WHO recommends the use of Z-score indicators of weight-forage (WAZ) (under-weight), height-for-age (HAZ) (stunting) and weight-for-height (WHZ) (wasting). To compute the anthropometric indices, information on each individual's gender, age, weight, and height are needed. WHZ and HAZ are the most commonly used indices for determining nutritional status. The former is an indicator of wasting (i.e. thinness indicating acute malnourishment) and the latter is an indicator of stunting (i.e. shortness indicating chronic malnourishment). The third index, WAZ, is primarily a composite of WHZ and HAZ and is considered to represent acute and chronic malnourishment. These indices present the long- and short-term prevalence of malnutrition in children. In the ADHS 2000 survey, "heights for children younger than 24 months were measured lying on a measuring board and standing height was measured for older children. Weight data were obtained using digital scales with an accuracy of $100 \mathrm{~g}$ " [1]. For measuring child's age a series of techniques were applied in order to maintain accuracy. In addition to asking mothers in what month and year the child was born, the mothers were also asked, "How old was your child at his/ her last birthday?" In addition, interviewers asked the mothers for birth cards or certificates in cases where one was available and cross checked the responses.

The procedure for the computation of these measures and their interpretation are well documented [19-22]. In our study, the values of WAZ, WHZ and HAZ were calculated using the Epi-Nut program provided along with the Epi-Info, version 6.03.
This program transforms the international growth reference curves into a Z-score representation. These growth reference curves have been used worldwide since 1978 to assess the nutritional status of children in cross-sectional surveys. Smoothed normalized curves are fitted by polynomial regression and cubic spline techniques and these curves are used to calculate all other normalized Z-score values. The standard deviations are defined separately for the upper and lower half of the skewed reference distributions. It has been argued that the use of Z-score cut-off points provides interpretative guidance in that a known proportion of the reference population would be expected to be below the cut-off point at any given age or height and for all indicators $[19,20]$. The commonly used conservative cut-off value of $Z$-score less than $-2 \mathrm{SD}$ is followed in our analysis.

Once the measures of malnutrition were calculated for each of the 3 indices, measures of parental and socioeconomic conditions were identified. The basic causes at the societal level can be divided into 2 types: potential resources and quantity and quality of actual resources. Potential resources are understood in terms of political, cultural, religious, economic and social subsystems present in the society and include conditions such as women's status in the society [23]. The potential resources, in turn, influence the quantity and quality of actual resources. The quantity and quality of the resources available is shaped by the human, economic, and organizational manner in which they are controlled [23]. For the purposes of this paper, the basic causes at the societal level were measured in terms of place of residence, consanguinity between parents, parents' level of education, mother's employment status, mother's height, and child's sex.

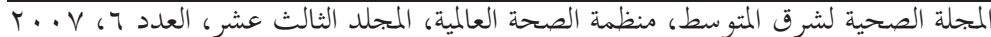


Place of residence was identified as rural or urban. Consanguinity between the parents was measured as: no relation, first degree, second degree, or other blood relative. Father's education was measured as no formal education, primary school, secondary school, or higher education. Mother's education was measured as no formal education, primary school, secondary school, or higher education. Mother's employment was identified as working outside the home or not working outside the home. Mother's height was measured in centimetres as: $<150 \mathrm{~cm}, 150-160 \mathrm{~cm}$, or $>160 \mathrm{~cm}$. The sex of the child was measured as male or female.

The second level identified in the UNICEF model considers underlying causes at the household/family level [6]. Central to these underlying causes are the maternal and child care practices and include many factors linked to family planning activities. In this paper, mother's age at birth of her last child, child's age, birth order and birth interval were included. The age of mother at birth was measured as $<19$ years of age, 19-24 years, 25-34 years or $\geq 35$ years. The age of the child at the time of data collection was measured in months as $0-11$ months, $12-23$ months, 24-35 months, 36-47 months or 48-59 months. The birth order was identified as 1, 2, 3, 4 or 5 and higher. Birth intervals were first born, 0-23 months, 24-35 months, 36-47 months or $\geq 48$ months.

A logistic regression technique was used to estimate the odds of being malnourished. This technique permits control of the parental and socioeconomic variables. To create the dependent variable, the children whose $\mathrm{Z}$-scores were less than $2 \mathrm{SD}$ were coded as 1 and the children with Z-scores of -2 SD or higher were coded as 0 . The following was the basic model used in the analysis: $\mathrm{Y}_{i j}=\mathrm{a}$ $+\mathrm{bX}_{i j}+\mathrm{cP}_{j}+\mathrm{m}_{j}+\mathrm{e}_{i j}$; where: $\mathrm{Y}_{i j}$ : outcome variable, $\mathrm{X}_{i j}$ : individual control variables, $\mathrm{P}_{j}$ : variables at the community (PSU) level, $\mathrm{m}_{j}$ : error of unobserved community variables and $\mathrm{e}_{j j}$ : error of unobserved individual variables. The basic assumption is that $\mathrm{m}_{j}$ is uncorrelated with the regressors; in other words, the above model considers the sample design as well. Specifically, the model predicting the probability that the Z-score value will fall below -2 SD (i.e. malnourished) takes the form: $p(\mathrm{z}=1)=e^{Y} /(1+$ $\left.e^{Y}\right)$.

The predictor variables entered in the regression equation are sets of dummy variables. Thus, the results obtained were compared with the reference category. The predictor variables used in the logistic regression model were: current place of residence, sex of the child, mother's education, father's education, birth spacing between the child and the previous birth, birth order, age of mother at the time of the child's delivery and age of the child at the time of survey. The reference categories for the different variables mentioned above were: living in a rural area, female child, maternal illiteracy, paternal illiteracy, birth spacing < 24 months, birth order of $\geq 5$, mother's age at child's birth $<19$ years and age of child $<12$ months old respectively. All outliers in anthropometric measures were deleted prior to data analysis. The Epi-Nut program flagged 32 cases as outliers by default and further investigation of data did not show any additional outliers. The statistical analysis was performed using $S A S 9.1$ statistical software for windows.

\section{Results}

Table 1 presents the percentage distribution of children below -2 SD units for the 3 anthropometric measures (wasting, stunting and underweight) according to selected 
parental and socioeconomic characteristics. Based on a theoretical distribution, it would be expected that $2.2 \%$ of children would be below -2 SD. On this basis, the 3 measures of under-nutrition were greater than would be expected. Among children under 5 years of age in Egypt, $18.67 \%$ were stunted (low height-for-age), $2.52 \%$ were wasted (low weight-for-height) and 4.06\% were underweight (low weight-for-age).

The prevalence of stunting was higher among rural children $(21.79 \%)$ as compared to urban children $(13.79 \%)$. The proportion of children with stunting fell as parents education increased. For example, among mothers and fathers with no education, $22.56 \%$ and $23.26 \%$ respectively of the children were stunted compared to $13.81 \%$ and $12.53 \%$ respectively among mothers and fathers with higher than secondary education. A sharp decline in stunting was observed with an increase in mother's height. Among mothers $<150 \mathrm{~cm}$ tall, $30.89 \%$ of the children were stunted; the percentage decreased to $13.61 \%$ of children with mothers $>160 \mathrm{~cm}$ tall. Children of mothers working outside the home had a lower prevalence of stunting $(17.76 \%)$ than those whose mothers who did not $(18.82 \%)$. Stunting was higher among children born to mothers married to close relatives; approximately $22 \%$ of children born to mothers married to their first cousins (father's or mother's side) were stunted compared to those born to mothers with no blood relation to their husbands. Stunting was higher in male children $(19.85 \%)$ than female children $(17.42 \%)$. Higher levels of stunting were found in children of higher birth order $(24.31 \%$ for birth order $\geq 5$ vs $17.26 \%$ birth order 1 ) and shorter birth intervals $(23.44 \%$ for birth interval $<23$ months vs $16.7 \%$ birth interval $\geq 48$ months). Children born to mothers aged $<19$ years and $\geq 35$ years showed a higher prevalence of stunting than children born to mothers in other age groups, $19.53 \%$ and $21.35 \%$ respectively. Just over $15 \%$ of children aged $0-11$ months at the time of the survey were stunted as were $23.44 \%$ of children aged 12-23 months.

While lower than the prevalence of stunting, at $2.52 \%$ wasting was still greater than the expected $2.2 \%$. There were no generally clear patterns seen for stunting with the different variables (Table 1). As regards under-nutrition, $4.06 \%$ of children under 5 years were under-nourished. The patterns seen were generally fairly similar to those of stunting (Table 1).

Although all 3 measures of under-nutrition were higher than would be expected, the highest prevalence was found in stunting (chronic malnourishment) (HAZ); $18.67 \%$ of the children under age 5 years were stunted. As this was the most prevalent form of under-nutrition in Egypt, the subsequent analysis focused on stunting only. Multivariate analysis was carried out to find the odds of stunting among children (Table 2). Since the birth interval variable was calculated only for births of second and higher orders, the multivariate analysis excluded the first order births.

Several variables were found to have a significant influence on the prevalence of stunting in Egypt. The odds of children being stunted in urban areas were 0.71 times lower than for children in rural areas. While not all categories of mother's education were statistically significant, they were in the expected direction. That is, as the maternal educational level increased, the odds of children being stunted decreased. While no clear and significant pattern was observed with father's education on stunting, the odds of stunting were 0.76 times lower among children whose fathers had at least higher secondary education as compared to children born to fathers with no education. Mother's height was found to

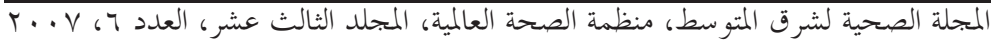


Table 1 Percentage of children under 5 years with Z scores below -2SD from the International Reference Population median by selected background characteristics, Egypt, 2000

\begin{tabular}{|c|c|c|c|c|}
\hline Characteristic & $\begin{array}{c}\text { Height-for- } \\
\text { age } \\
\text { (stunting) } \\
\%\end{array}$ & $\begin{array}{c}\text { Weight-for- } \\
\text { height } \\
\text { (wasting) } \\
\%\end{array}$ & $\begin{array}{c}\text { Weight-for- } \\
\text { age } \\
\text { (underweight) } \\
\%\end{array}$ & $\begin{array}{l}\text { Number of } \\
\text { children } \\
\text { included in } \\
\text { the analysis }\end{array}$ \\
\hline \multicolumn{5}{|l|}{ Place of residence } \\
\hline Urban & 13.79 & 2.34 & 3.01 & 3972 \\
\hline Rural & 21.79 & 2.63 & 4.73 & 6222 \\
\hline \multicolumn{5}{|l|}{ Mother's education } \\
\hline No education & 22.56 & 2.47 & 5.35 & 4046 \\
\hline Primary & 19.76 & 2.4 & 3.60 & 1573 \\
\hline Secondary & 15.11 & 2.69 & 3.18 & 3722 \\
\hline Higher & 13.81 & 2.19 & 2.61 & 853 \\
\hline \multicolumn{5}{|c|}{$\begin{array}{l}\text { Mother's working status outside } \\
\text { the home }\end{array}$} \\
\hline Yes & 17.76 & 2.54 & 3.31 & 1429 \\
\hline No & 18.82 & 2.51 & 4.18 & 8765 \\
\hline \multicolumn{5}{|l|}{ Mother's height $(\mathrm{cm})$} \\
\hline$<150$ & 30.89 & 1.74 & 6.35 & 999 \\
\hline $150-160$ & 19.20 & 2.60 & 4.02 & 6085 \\
\hline $160+$ & 13.61 & 2.62 & 3.39 & 3077 \\
\hline \multicolumn{5}{|c|}{ Consanguinity of the parents } \\
\hline No relation & 16.72 & 2.49 & 3.48 & 6244 \\
\hline First degree & 21.99 & 2.45 & 5.08 & 2322 \\
\hline Second degree & 21.87 & 2.29 & 5.03 & 1016 \\
\hline Other blood relative & 20.65 & 3.38 & 4.47 & 612 \\
\hline \multicolumn{5}{|l|}{ Father's education } \\
\hline No education & 23.26 & 2.34 & 5.72 & 2522 \\
\hline Primary & 18.66 & 3.02 & 4.12 & 2106 \\
\hline Secondary & 17.96 & 2.31 & 3.36 & 4182 \\
\hline Higher & 12.53 & 2.7 & 3.06 & 1380 \\
\hline \multicolumn{5}{|l|}{ Sex of child } \\
\hline Male & 19.85 & 2.86 & 4.44 & 5252 \\
\hline Female & 17.42 & 2.15 & 3.66 & 4942 \\
\hline \multicolumn{5}{|l|}{ Birth order of child } \\
\hline 1 & 17.26 & 2.89 & 3.64 & 2757 \\
\hline 2 & 16.34 & 2.06 & 2.87 & 2420 \\
\hline 3 & 17.71 & 2.57 & 3.44 & 1759 \\
\hline 4 & 18.31 & 2.18 & 4.02 & 1185 \\
\hline $5+$ & 24.31 & 2.70 & 6.57 & 2073 \\
\hline \multicolumn{5}{|l|}{ Birth interval (months) } \\
\hline First birth & 17.26 & 2.89 & 3.64 & 2757 \\
\hline $0-23$ & 23.40 & 2.92 & 6.24 & 1748 \\
\hline $24-35$ & 19.83 & 2.3 & 3.46 & 2172 \\
\hline
\end{tabular}


Table 1 Percentage of children under 5 years with $Z$ scores below -2SD from the International Reference Population median by selected background characteristics, Egypt, 2000 (concluded)

\begin{tabular}{lcccc}
\hline Characteristic & $\begin{array}{c}\text { Height-for- } \\
\text { age } \\
\text { (stunting) } \\
\%\end{array}$ & $\begin{array}{c}\text { Weight-for- } \\
\text { height } \\
\text { (wasting) } \\
\%\end{array}$ & $\begin{array}{c}\text { Weight-for- } \\
\text { age } \\
\text { (underweight) } \\
\%\end{array}$ & $\begin{array}{c}\text { Number of } \\
\text { children } \\
\text { included in } \\
\text { the analysis }\end{array}$ \\
\hline $\begin{array}{l}\text { 36-47 } \\
\text { 48+ }\end{array}$ & 16.67 & 2.79 & 4.59 & 1359 \\
Age of mother at birth (years) & 16.7 & 1.74 & 3.13 & 2121 \\
$<$ 19 & 19.53 & 2.55 & 4.2 & \\
19-24 & 18.96 & 2.57 & 3.83 & 3774 \\
25-34 & 17.74 & 2.53 & 4.11 & 4732 \\
35+ & 21.35 & 2.23 & 4.6 & 1042 \\
Age of child at survey time & & & & \\
(months) & & & & \\
0-11 & 15.1 & 4.65 & 4.13 & 2070 \\
12-23 & 23.44 & 3.13 & 5.75 & 205 \\
24-35 & 19.20 & 1.75 & 3.77 & 2114 \\
36-47 & 17.24 & 1.11 & 2.86 & 2048 \\
48-59 & 18.39 & 1.91 & 3.78 & 1911 \\
Total & 18.67 & 2.52 & 4.06 & 10194 \\
\hline
\end{tabular}

a Total includes 4 children for whom information on father's education was not known and 37 and 33 children with missing information on birth interval and height of the mother respectively.

have a significant influence on the odds of stunting. Children born to mothers whose height was $150-160 \mathrm{~cm}$ had 0.60 times lower odds of stunting than children born to mothers whose height was $<150 \mathrm{~cm}$ and odds were 0.41 times lower if mother's height was $>160 \mathrm{~cm}$. Children whose parents were first cousins had 1.21 higher odds of being stunted compared to children whose parents were not blood relations; the odds of stunting were 1.22 times higher if the parents were second cousins. The odds of stunting were significantly lower among low birth order children (3 or less) compared to children of birth order 5 and above. The odds of stunting were higher among children age 12-23 months (1.79 times) and 24-35 months (1.28 times) than children aged $<12$ months. Birth intervals had a significant influence on stunting; the odds of being stunted declined as the birth interval increased. Other variables found not to be significantly associated with the odds of stunting were: mother's working status, male sex and age of mother at time of birth (Table 2).

\section{Discussion}

Measuring the weight and height of the child actually measures much more than a single child, these also measure the future of a country. Child health has a prominent role in shaping and defining the structure of a society. It shapes the quality of future human capital, helps population stabilization and furthers future economic growth, among other factors. In the case of Egypt, there have been marked improvements over

المجلة الصحية لشرق المتوسط، منظمة الصحة العالمية، المجلد الثالث عشر، العدد Y، V... 


\begin{tabular}{|c|c|c|c|}
\hline Characteristic & Odds ratio & SE & $\begin{array}{c}95 \% \text { confidence } \\
\text { interval }\end{array}$ \\
\hline \multicolumn{4}{|l|}{ Place of residence } \\
\hline Urban & $0.71^{* *}$ & 0.0975 & $0.5903-0.8656$ \\
\hline \multicolumn{4}{|l|}{ Mother's education ${ }^{b}$} \\
\hline Primary & 0.95 & 0.1005 & $0.7776-1.1540$ \\
\hline Secondary & $0.77^{*}$ & 0.1176 & $0.6147-0.9753$ \\
\hline Higher & 0.73 & 0.2427 & $0.4553-1.1806$ \\
\hline \multicolumn{4}{|l|}{ Mother's working status ${ }^{c}$} \\
\hline Yes & 1.13 & 0.1152 & $0.9002-1.4153$ \\
\hline \multicolumn{4}{|l|}{ Mother's height $(\mathrm{cm})^{d}$} \\
\hline $150-160$ & $0.60^{\star * \star}$ & 0.0947 & $0.4975-0.7216$ \\
\hline $160+$ & $0.41^{* * *}$ & 0.1100 & $0.3302-0.5086$ \\
\hline \multicolumn{4}{|c|}{ Consanguinity of the parents ${ }^{e}$} \\
\hline First degree & $1.21^{* *}$ & 0.0835 & $1.0280-1.4269$ \\
\hline Second degree & $1.22^{*}$ & 0.1097 & $0.9858-1.5165$ \\
\hline Other blood relative & $1.32^{*}$ & 0.1339 & $1.0155-1.7177$ \\
\hline \multicolumn{4}{|l|}{ Father's education ${ }^{f}$} \\
\hline Primary & 0.82 & 0.1038 & $0.6726-1.0111$ \\
\hline Secondary & 0.95 & 0.1035 & $0.7748-1.1634$ \\
\hline Higher & 0.76 & 0.1910 & $0.5225-1.1059$ \\
\hline \multicolumn{4}{|l|}{ Sex of childg } \\
\hline Male & 1.05 & 0.0705 & $0.9124-1.2032$ \\
\hline \multicolumn{4}{|l|}{ Birth order of child ${ }^{h}$} \\
\hline 2 & $0.70^{* * *}$ & 0.1233 & $0.5496-0.8918$ \\
\hline 3 & $0.82^{*}$ & 0.1137 & $0.6537-1.0214$ \\
\hline 4 & 0.82 & 0.1087 & $0.6596-1.0108$ \\
\hline \multicolumn{4}{|c|}{ Age of mother at birth (years)' } \\
\hline $19-24$ & 0.76 & 0.2246 & $0.4918-1.1877$ \\
\hline $25-34$ & 0.70 & 0.2298 & $0.4465-1.1008$ \\
\hline $35+$ & 0.78 & 0.2560 & $0.4719-1.2895$ \\
\hline \multicolumn{4}{|l|}{ Age of child (months) ${ }^{j}$} \\
\hline $12-23$ & $1.79^{\star * *}$ & 0.1055 & $1.4559-2.2032$ \\
\hline $24-35$ & $1.28^{* *}$ & 0.1097 & $1.0348-1.5921$ \\
\hline $36-47$ & 1.03 & 0.1156 & $0.8186-1.2890$ \\
\hline $48-59$ & $1.24^{*}$ & 0.1126 & $0.9949-1.5483$ \\
\hline \multicolumn{4}{|l|}{ Birth interval (months) ${ }^{k}$} \\
\hline $24-35$ & $0.79^{* * *}$ & 0.0871 & $0.6653-0.9364$ \\
\hline $36-47$ & $0.67^{* * *}$ & 0.1020 & $0.5520-0.8238$ \\
\hline $48+$ & $0.66^{* * *}$ & 0.1037 & $0.5385-0.8091$ \\
\hline Constant & 0.83 & 0.2721 & $0.4888 ; 1.4230$ \\
\hline
\end{tabular}

Reference categories: arural; b,f no education; ' ${ }^{\text {not }}$ working: ${ }^{\circ}<150 \mathrm{cms}$; ${ }^{\circledR}$ no relationship; gfemale; ${ }^{h} 5+; i<19$ years, ${ }^{j}<12$ months; ${ }^{k}<24$ months.

${ }^{*} \mathrm{P}<0.05 ;{ }^{* *} \mathrm{P}<0.01 ;{ }^{* * *} \mathrm{P}<0.001$.

SE $=$ standard error 
the past 10 years in the nutritional status of children but much work remains to be done. In order to further decrease levels of childhood malnutrition in Egypt, policy frameworks must be established that incorporate short-term, medium-term and longterm strategies to solve nutritional problems [24]. The intervention strategies should be comprehensive, culturally sensitive and, as malnutrition is a public health concern, addressed at various levels of government.

Based on the findings of this research, policy development must take into consideration the rural-urban divide in malnutrition. It is clear that children raised in rural areas are at greater risk for under-nutrition. Our results support the findings of prior studies that have also described the urbanrural differences in health in Egypt. People living in urban areas are provided with better access to health services, education and other social support systems which are either not available or not easily accessible to residents in rural areas. For example, studies have shown that immunization rates are higher in urban areas as compared to rural areas of Egypt [25]. Programmes should thus be developed to analyse and implement appropriate strategies to address rural and urban child malnutrition. For example, in Egypt most nutritionists are based in urban hospitals while cases of malnutrition in rural areas are unlikely to seek care in such hospitals [26]. Improvements in access to care in rural areas together with the introduction of awareness programmes will have a significant impact on ameliorating the existing nutritional conditions in children.

Programmes should be developed that target higher risk groups such as young children and higher birth order children. Further research and needs assessments are required to examine this situation in order to design intervention programmes. The fact that risks are different at different ages sug- gests the need for age-specific interventions to address the nutritional needs of children. Additionally, family planning conditions such as birth interval, which was found to be very important in our study, need to be considered. This finding supports the idea that rearing children requires a large amount of resources and attention. When children are born closely together, the demands on resources such as mother's time, food, and other resources may be greater than the family can provide. Our findings therefore suggest that greater spacing of children could help to address under-nutrition by relieving competition and exhaustion of available resources.

While socioeconomic conditions certainly have an effect on the nutritional status of children, there is growing recognition that genetic factors must be considered as well. There have been calls for the inclusion of genetic characteristics in the study of child health and nutrition [27,28] but genetic components have not been adequately examined in many studies [29]. The inclusion of 2 genetic factors in this study is an important contribution to the literature on childhood nutritional status. The 2 genetic characteristics (mother's height and parental consanguinity) emerged as significant factors influencing stunting of children in Egypt. Consanguinity in a population depends on several factors such as demographic, social and religious norms and values. Many studies have shown conflicting results on the impact of consanguineous marriages on childhood health [30-32]. Children born to consanguineous parents are at an increased risk of autosomal recessive disorders, multifactorial diseases [30] and early postnatal mortality [33,34]. These disease processes can produce disorders similar to nutrient deficiency and may result in the appearance of stunting [24]. Although there are conflicting opinions,

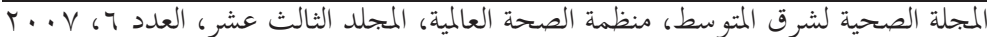


nutritional studies have seldom included this phenomenon. More studies are thus needed in this area to explore further the influence of genetic characteristics on early childhood nutrition in Egypt and elsewhere. From a policy implementation perspective, the issue of consanguinity will require cultural sensitivity to the issue [24]. To address consanguinity, educational programmes could be instigated to create awareness, particularly among young unmarried males and females, about the potential risks associated with consanguineous marriage. Additionally, genetic counselling and risk assessment for consanguineous couples would assist families in making family planning decisions that could have an impact on the nutritional and health status of their children.

The results of our study show the importance of the UNICEF model incorporating parental and socioeconomic characteristics in understanding the prevalence of undernutrition, especially stunting, in Egypt. The framework classifies the causes of malnutrition to account for the complexity of the nutritional status of children. At the basic level, rural conditions and the status of women in society have an important contribution to the nutritional status of children. Specifically, children in rural areas are at greater risk of stunting. Regarding women's status in society, education and the practice of consanguinity contributed to the childhood malnutrition. Family planning factors as underlying causes at the household/family level were also found to be important aspects of the UNICEF model. Specifically, birth order and birth interval were important factors and relate to inadequate maternal and childcare practices. Further research is needed to explore the influence of additional basic level causes and underlying causes at the family/household level as well as inclusion of immediate causes such as the presence of disease and dietary intake in the child.

These factors should be considered in the development of any policies or programmes aimed at alleviating the problem of under-nutrition. Among all factors, parental characteristics, mother's characteristics in particular, were found to have a significant impact on determining the nutritional status of children. Empowerment of women through increasing educational levels, choice in marriage, family planning, and other activities that improve the status of women in society must be a priority in programme and policy development aimed at addressing the factors associated with under-nutrition in children in Egypt.

Hameida and Billot argue that "to measure the weight and height of a child is to measure his or her health" [35]. In the present study we assessed the factors that contribute to the health condition of the child. More specifically, we considered basic and underlying conditions that affect the nutritional status of children in Egypt. The study results further strengthen our understanding about the nutritional status of children in Egypt. Although, at the national level, the prevalence of under-weight and wasting has decreased since 1995 , these estimates are still higher than would be desired. Most alarmingly, the high prevalence of stunting signifies a public health problem; the anthropometric measures show estimates of stunting above international standards. Stunting is so prevalent that almost one child in every five children under the age of 5 years in Egypt is stunted. The documented decrease in childhood stunting in Egypt is promising but more work must be done to address the issues of childhood malnutrition if the gains are to be sustained and further progress achieved. 


\section{References}

1. El-Zanaty F, Way AA. Egypt Demographic and Health Survey 2000. Calverton, Maryland (USA); Cairo, Ministry of Health and Population, National Population Council and ORC Macro, 2001.

2. Human Development Report 2004: Cultural liberty in today's diverse world. New York, United Nations Development Programme, 2004.

3. Pelletier D, Frongillo Jr EA, Habicht JP. Epidemiologic evidence for a potentiating effect of malnutrition on child mortality. American journal of public health, 1993, 83(8):1130-3.

4. A critical link. Interventions for physical growth and psychological development: a review. Geneva, World Health Organization, 1999 (WHO/CHS/CAH/99.3).

5. De Onis M, Frongillo EA, Blossner M. Is malnutrition declining? An analysis of changes in levels of child malnutrition since 1980. Bulletin of the World Health Organization, 2000, 78(10):1222-33.

6. United Nations Children's Fund. The state of the world's children 1998. Oxford, Oxford University Press, 1998.

7. Smith L, Haddad N. Overcoming child malnutrition in developing countries: past achievement and future choices. Washington DC, International Food Policy Research Institute, 2000.

8. Sommerfelt AE. Comparative analysis of the determinants of children's nutritional status. Paper presented at the Demographic and Health Surveys World Conference, Washington DC, 5-7 August, 1991.

9. Wagstaff A, Watanabe N. Socioeconomic inequalities in child malnutrition in the developing world. Washington DC, The World Bank, 2000 (Population Policy Research Working Paper Series No. 2434)

10. Rajaram S, Sunil TS, Zottarelli LK. An analysis of childhood malnutrition in Kerala and Goa. Journal of biosocial science, 2003, 35:335-51.
11. Family Planning Saves Lives. Washington DC, Population Reference Bureau, 1996.

12. Nutrition profile of the WHO South-East Asia Region. New Delhi, World Health Organization Regional Office for South-East Asia, 2000

13. Behrman JR. Nutrition, health, birth order and seasonality: intrahousehold allocation among children in rural India. Journal of development economics, 1988, 28(1):43-62.

14. United Nations Children's Fund. Strategy for improved nutrition of children and women in developing countries, New York, Oxford University Press, 1990.

15. Yassin, K. Morbidity and risk factors of diarrheal diseases among under-five children in rural upper Egypt. Journal of tropical pediatrics, 2000, 46:282-7.

16. El-Sayeed $\mathrm{N}$ et al. Malnutrition among pre-school children in Alexandria, Egypt. Journal of health population nutrition, 2001, 19(4):275-80.

17. Aref $\mathrm{GH}$ et al. Clinical and radiologic study of the frequency and presentation of chest infection in children with severe protein energy malnutrition. Journal of Egyptian Public Health Association, 1992, 67(5-6):655-73.

18. Ashour $\mathrm{MN}$ et al. Antioxidant status of children with protein-energy malnutrition (PEM) living in Cairo, Egypt. European journal of clinical nutrition, 1999, 52:66973.

19. Physical status: the use and interpretation of anthropometry. Report of a WHO Expert Committee. Geneva, World Health Organization, 1995 (WHO Technical Report Series, No. 854).

20. Waterlow JC et al. The presentation and use of height and weight data for comparing the nutritional status of groups of children under the age of 10 years. Bulletin of the World Health Organization, 1977, 55:489-98.

المجلة الصحية لشرق المتو سط، منظمة الصحة العالمية، المجلد الثالث عشر، العدد ب، V... 
21. Dibley MJ et al. Development of normalized curves for the international growth reference: historical and technical considerations. American journal of clinical nutrition, 1987, 46:736-48.

22. Dibley $\mathrm{MJ}$ et al. Interpretation of Z-score anthropometric indicators derived from the international growth reference, American journal of clinical nutrition, 1987 , 46:749-62.

23. The progress of nations. New York, United Nations Children's Fund, 1997.

24. Aoyama A. Toward a virtuous circle: a nutrition review of the Middle East and North Africa. Washington DC, The World Bank, 1999.

25. El-Kogali S, El-Daw S. Poverty, human capital \& gender: a comparative study of Yemen \& Egypt. Cairo, Economic Research Forum, 2001 (Working paper 0123).

26. Aoyama A, Ferrinho P. Arab Republic of Egypt: the situation of human resource development and management of the health sector - a background document for the Egypt Health Sector Reform Project. Washington DC, The World Bank, 1997.

27. Ruel MT et al. Screening for nutrition interventions: the risk or the differentialbenefit approach? American journal of clinical nutrition, 1996. 63:671-7.

28. Adair $L$ et al. Growth dynamics during the first two years of life: a prospective study in the Philippines. European journal of clinical nutrition, 1993, 47(1):42-51.

29. Sichieri R, Taddei JA, Everhart JE. Influence of parental height and sociodemographic factors on adolescent height in Brazil. Journal of adolescent health, 2000, 26:414-9.

30. Bittles $\mathrm{AH}$. Consanguinity and its relevance to clinical genetics. Clinical genetics 2001, 60:89-98.

31. Bittles $\mathrm{AH}$. Consanguineous marriage and childhood health. Developmental medicine and child neurology, 2003, 45(8):571-6.

32. Saadat M, Ansari-Lari M, Farhud DD. Consanguineous marriage in Iran. Annals of human biology, 2004, 31:263-9.

33. Al Husain M, Al Bunyan M. Consanguineous marriages in a Saudi population and the effect of inbreeding on prenatal and postnatal mortality. Annals of tropical paediatrics, 1997, 17:155-60.

34. Hussain R, Bittles AH. Sociodemographic correlates of consanguineous marriages in the Muslim population in India. Journal of biosocial science, 2000, 32:433-42.

35. Hamieda J, Billot L. Nutritional status of Libyan children in 2000 compared with 1979. Eastern Mediterranean health journal, 2002, 8(2 \& 3):1-10. 